\title{
PENERAPAN METODE MODELING THE WAY UNTUK MENINGKATKAN KREATIVITAS BELAJAR SISWA PADA MATERI EKOSISTEM KELAS VII MTS. NEGERI JONGGAT TAHUN PELAJARAN 2015/2016
}

\author{
Lestari Wahyu Putri ${ }^{1}$, Adi Fadli ${ }^{2}$ dan Hadi Kusuma Ningrat ${ }^{3}$ \\ 1Jurusan Pendidikan IPA Biologi FITK IAIN Mataram \\ 2,3,Dosen Jurusan Pendidikan IPA Biologi FITK IAIN Mataram
}

\begin{abstract}
Abstrak
Penelitian ini bertujuan untuk mengetahui proses penerapan metode modeling the way untuk meningkatkan kreativitas belajar siswa pada materi ekosistem kelas VII MTs. Negeri Jonggat Tahun Pelajaran 2015-2016. Penelitian ini merupakan penelitian tindakan kelas (PTK), Pendekatan yang digunakan adalah pendekatan kualitatif. Instrumen yang digunakan dalam pengumpulan data penelitian ini adalah pedoman observasi keterlaksanaan RPP, pedoman dokumentasi, angket, dan pedoman wawancara. penelitian ini dilakukan di kelas VII A MTs. Negeri Jonggat dengan jumlah siswa 32 orang yang terdiri dari 17 orang perempuan dan 15 orang laki-laki. Dalam penelitian ini peneliti menemukan bahwa dengan menerapkan metode modeling the way dapat meningkatkan kreativitas belajar siswa dari pada pembelajaran yang mengguakan metode yang relatif monoton. Hal ini dapat terlihat dari hasil observasi aktivitas guru/ keterlaksanaan RPP, yang setiap siklus mengalami peningkatan dimana pada siklus I persentase keterlaksanaan RPP mencapai 85\%, siklus II dan siklus III mencapai 100\%. Sedangkan pada hasil observasi angket kreativitas belajar siswasetiap siklus mengalami peningkatan, pada siklus I jumlah kreativitas seluruh siswa 1182 dengan nilai rata-rata 36,9 dengan kategori kreativitas cukup, siklus II jumlah kreativitas seluruh siswa 1540 dengan nilai rata-rata 48,1 dengan kategori kreativitas baik, dan siklus III jumlah kreativitas belajar siswa 1703 dengan nilai rata-rata 53,21 dengan kategori kreativitas sangat baik.
\end{abstract}

Kata Kunci: Metode Modeling the way , Kreativitas Belajar 


\section{PENDAHULUAN}

Pendidikan merupakan suatu proses dalam rangka mempengaruhi siswa agar dapat menyesuaikan diri sebaik mungkin terhadap lingkungannya. Dengan pendidikan, tidak diharapkan muncul manusia-manusia yang lain dan asing terhadap masyarakatnya, tetapi manusia yang lebih bermutu, mengerti, dan mampu membangun masyarakatnya. Sesuai dengan tujuan pendidikanyang sering dirumuskan untuk menyiapkan generasi muda menjadi orang dewasa anggota masyarakat yang mandiri dan produktif.

Selain itu pendidikan juga berintikan interaksi antara pendidik (guru) dan peserta didik (siswa) untuk mencapai tujuantujuan pendidikan. Hubungan yang terjalin antara guru dan murid dalam proses belajar mengajar merupakan suatu inti dari sebuah proses dalam suatu pendidikan, jika suatu proses belajar mengajar tidak akan terjadi tanpa adanya hubungan interaksi yang baik antara guru dengan murid, dan suatu tujuan dari pendidikan pun tidak akan tercapai.

Sebagai tenaga pengajar, guru bisa disebut the trainer, sebab sebagian tugas atau pekerjannya mengandung unsur memberikan pelatihan kepada para siswa. Akan tetapi, tidak semua guru memahami dan/atau menyadari paradigma kebiasaan-kebiasaan belajar mengajar selama ini. Praktikpraktik pengajaran masih banyak yang didominasi oleh guru dan bahkan guru sepertinya memiliki otoritas untuk memaksa siswa memenuhi semua yang diinginkannya, dengan kurang bijak memperhatikan kebutuhan belajar siswanya.

Penerapan metode modeling the way pada mata pelajaran IPA memiliki tujuan untuk membantu para peserta didik mengidentifikasi masalah-masalah apa saja yang muncul dalam kehidupan lingkungan sekitar dan mencari solusi atau cara yang tepat untuk mengatasi masalah tersebut, sehingga peserta didik dibimbing untuk menemukan sebuah konsep permasalahan yang timbul dalam kehidupan nyata dan memprosesnya melalui pembelajaran.

Tujuan yang ingin dicapai dalam penelitian ini adalah untuk meningkatkan kreativitas belajar siswa pada materi 
ekosistem kelas VII MTs. NegeriJonggat tahun pelajaran 2015/2016 melalui penerapan metode modeling the way.

\section{METODE PENELITIAN}

\section{Setting Penelitian}

Penelitian ini telah dilaksanakan di MTs. Negeri Jonggat Kecamatan Jonggat Kabupaten Lombok Tengah, Adapun subjek tindakan dalam penelitian ini adalah kelas VII A yang berjumlah 32 siswa yang terdiri dari 17 orang perempuan dan 15 orang laki-laki. Penelitian ini akan dilakukan pada semester genap tahun pelajaran2015/2016.

\section{Rencana Tindakan}

Penelitian ini merupakan penelitian tindakan kelas (PTK) yang direncanakandalam 3 (Tiga) siklus, masing-masing siklus terdiri dari 4 (empat) tahapan yaitu perencanaan tindakan, pelaksanaan tindakan, observasi, dan refleksi.

Jenis Instrumen dan Cara Penggunaannya

1. Pedoman Observasi

2. Angket (Kuesioner)

3. Pedoman Dokumentasi

4. Pedoman Wawancara

\section{Pelaksanaan Tindakan}

Adapun alur pelaksanaan tindakan pada setiap siklus dilaksanakan sesuai dengan langkah-langkah metode modeling the way.

\section{Cara Pengamatan (Monitoring),}

Adapun yang bertindak sebagai observer adalah guru bidang studi IPA dan 2orang teman sejawat. Guru bidang studi IPA mengobservasikan kegiatan peneliti (keterlaksanaan RPP) selama proses pembelajaran berlangsung sedangkan 2 orang teman sejawat mengobservasikan kegiatan dan membantu kegiatan dokumentasi siswa selama proses pembelajaran berlangsung. 


\section{Analisis dan Refleksi}

\section{a. Keterlaksanaan RPP}

Data hasil observasi tentang keterlaksanaan pembelajaran (RPP) dalam penelitian ini dianalisis dengan menggunakan rumus persentase berikut:

$$
\text { Keterlaksaan RPP }=\frac{x}{y} \times 100 \%
$$

Keterangan:

$\mathrm{X}=$ jumlahlangkahpembelajaranyangterlaksana.

$\mathrm{Y}=$ total langkahpembelajaranyangharusdilaksanakan

\section{b. Angket Kreativitas Belajar}

Angket terdiri dari 15 butir soal dengan 4 alternatif jawaban. Rumus yang digunakan untuk menghitung hasil angket adalah sebagai berikut:

\section{1) Rumus untuk menghitung hasil Angket Kreativitas Siswa setiap siswa}

Table 1

Skor yang Akan Diberikan Setiap Pernyataan

\begin{tabular}{|c|c|c|c|c|}
\hline \multirow{2}{*}{ Pertanyaan } & \multicolumn{4}{|c|}{ Bobot Penskoran } \\
\cline { 2 - 5 } & Selalu & Sering & $\begin{array}{c}\text { Kadang- } \\
\text { kadang }\end{array}$ & $\begin{array}{c}\text { Tidak } \\
\text { pernah }\end{array}$ \\
\hline Positif & 4 & 3 & 2 & 1 \\
\hline Negative & 1 & 2 & 3 & 4 \\
\hline
\end{tabular}

Jumlah butir item 15, menggunakan skala likert sehingga jumlah skor maksimal $4 \times 15=60$, dan jumlah skor minimal adalah 15.

Adapun kriteria penilaian:

$15 \leq$ Jumlah skor $<24$ : kreativitas kurang sekali

$24 \leq$ Jumlah skor< 34 : kreativitas kurang

$33 \leq$ Jumlah skor $<42$ : kreativitas cukup

$42 \leq$ Jumlah skor $<51$ : kreativitas baik

$51 \leq$ Jumlah skor $\leq 60$ : kreativitas baik sekali 
2) Rumus untuk menghitung rata-rata kreativitas siswa.

Rata-rata $=\underline{\text { Jumlah Skor Seluruh Siswa }}$ Jumlah Siswa

Adapun kriteria penilaian:

$15 \leq$ Jumlah skor $<24$ : kreativitas kurang sekali

$24 \leq$ Jumlah skor $<34$ : kreativitas kurang

$33 \leq$ Jumlah skor< 42 : kreativitas cukup

$42 \leq$ Jumlah skor $<51$ : kreativitas baik

$51 \leq$ Jumlah skor $\leq 60$ : kreativitas baik sekali

\section{HASIL DAN PEMBAHASAN}

Pada penelitian ini, data keterlaksanaan RPP dalam proses pembelajaran diperoleh dari lembar observasi sedangkan data kreativitas belajar siswa diperoleh melalui angket yang dberikan setelah pembelajaran. Adapun uraian pelaksanaan penelitian tindakan pada penelitian ini diuraikan sebagai berikut:

\section{Data Siklus 1}

\section{Tahap perencanaan}

Pada tahap perencanaan ini kegiatan yang dilakukan dalam menerapkan metode modeling the way peneliti dan guru mempersiapkan hal-hal berikut:

1) Menyusun rencana pelaksanaan pembelajaran (RPP)

2) Menyiapkan sumber belajar

3) Menyiapkan ringkasan materi yang akan diajarkan

4) Menyusun scenario pembelajaran dengan menggunakan metode modeling the way yang diterapkan dalam proses pembelajaran.

5) Membentuk kelompok belajar dengan persetujuan guru yang bersifat heterogen beranggotakan 6-7 orang.

6) Menyiapkan instrumen ukur berupa angket (kuesioner) untuk mengukur kreativitas belajar siswa 


\section{Tahap pelaksanaan tindakan}

Siklus 1 di mulai tanggal 13 Mei 2016 dengan materi pokok ekosistem.

\section{Data aktivitas guru/ keterlaksanaan RPP}

Dari hasil observasi aktivitas guru pada tabel di atas dapat dilihat bahwa dari 20 total langkah pembelajaran yang harus dilaksanakan dapat terlaksana 17 langkah pemelajaran, sehingga rata-rata aktivitas guru pada siklus I yaitu $85 \%$ dan dapat dikategorikan sangat baik pada siklus I.

\section{Tabel 2}

Hasil Observasi Nilai Angket Kreativitas Belajar Siswa Siklus I.

\begin{tabular}{|r|l|c|l|}
\hline No & \multicolumn{1}{|c|}{ Nama Siswa } & $\begin{array}{c}\text { Jumlah } \\
\text { Skor } \\
\text { Angket }\end{array}$ & Kriteria Penilaian \\
\hline 1 & Abdul Majid & 3 & Kreativitas kurang \\
\hline 2 & Abdul Makki & 3 & Kreaativitas cukup \\
\hline 3 & Adlina Noviana Hidayat & 3 & Kreativitas kurang \\
\hline 4 & Baiq Aisyah & 3 & Kreativitas kurang \\
\hline 5 & Bayu Permana & 4 & Kreativitas baik \\
\hline 6 & Deny Kurniawan & 3 & Kreativitas kurang \\
\hline 7 & Dzatu Salsabilla Nurdianti & 3 & Kreativitas cukup \\
\hline 8 & Elna Sri Hardini & 3 & Kreativitas cukup \\
\hline 9 & Frisca Ayudhia Putri & 3 & Kreativitas cukup \\
\hline 10 & Grace Davida Dimayanti & 2 & Kreativitas cukup \\
\hline 11 & Ifan Cahyoni & 3 & Kreativitas cukup \\
\hline 12 & Husnun Niswati & 4 & Kreativitas cukup \\
\hline 13 & Julian Salisti & 3 & Kreativitas kurang \\
\hline 14 & Lala Sugiatin Hasanah & 3 & Kreativitas cukup \\
\hline 15 & Lalu Alfito Dinata & 4 & Kreativitas cukup \\
\hline 16 & Lu'lu'atul Husna Izzati & 4 & Kreativitas cukup \\
\hline 17 & M. Rizal Alwi & 4 & Kreativitas baik \\
\hline 18 & M. Sadarti & 3 & Kreativitas cukup \\
\hline 19 & M. Zamroni Ansyori & 3 & Kreativitas cukup \\
\hline 20 & Mahendra & 3 & Kreativitas kurang \\
\hline 21 & Mely Apriana & 3 & Kreativitas cukup \\
\hline & & & \\
\hline
\end{tabular}


Tabel 2 lanjutan

\begin{tabular}{|r|l|c|l|}
\hline No & \multicolumn{1}{|c|}{ Nama Siswa } & $\begin{array}{c}\text { Jumlah } \\
\text { Skor } \\
\text { Angket }\end{array}$ & Kriteria Penilaian \\
\hline 22 & Novia Fitriani & 4 & Kreativitas baik \\
\hline 23 & Nurahmadan Noviana & 3 & Kreativitas cukup \\
\hline 24 & Rendi Aditia Hariadi & 3 & Kreativitas cukup \\
\hline 25 & Rozi Hartono & 3 & Kreativitas kurang \\
\hline 26 & Sovia Aprinda & 4 & Kreativitas baik \\
\hline 27 & Sri Cahyani & 3 & Kreativitas cukup \\
\hline 28 & Tio Febriansyah & 4 & Kreativitas cukup \\
\hline 29 & Urba Anisya & 3 & Kreativitas cukup \\
\hline 30 & Wahyuni Fadliatin & 3 & Kreativitas cukup \\
\hline 31 & Yuda Pratama & 4 & Kreativitas baik \\
\hline 32 & Zilmim Habib & 3 & Kreativitas kurang \\
\hline & Angket & 1182 & - \\
\cline { 2 - 4 } & Nilai rata-rata angket & $\mathbf{3 6 , 9}$ & Kreativitas cukup \\
\hline
\end{tabular}

Dari tabel di atas dapat dilihat bahwa nilai rata-rata kreativitas belajar siswa pada siklus I belum mencapai target yang diharapkan yaitu 36,9 , rata-rata siswa memiliki kreativitas belajar yang tergolong ke dalam kategori kreativitas cukup.

\section{Data Siklus II}

1. Tahap Perencanaan, sama dengan siklus 1.

\section{Tahap pelaksanaan tindakan}

Pada tahap pelaksanaan tindakan, siklus II di mulai tanggal 21 Mei 2016 dengan materi pokok ekosistem, Dimana pada siklus II ini, guru memperbaiki kekurangan-kekurangan yang belum disampaikan pada siklus I. Pada pelaksanaan siklus II ini, proses pembelajaran dilakukan di taman sekolah.

\section{Data Aktivitas Guru/ Keterlaksanaan RPP}

Dari hasil observasi aktivitas guru pada pelaksanaan dapat dilihat bahwa dari 20 total langkah pembelajaran dapat terlaksana keseluruhannya, sehingga aktivitas guru dapat dikategorikan sangat baik pada siklus II. 


\section{Tabel 3}

\section{Hasil Observasi Nilai Angket Kreativitas Belajar Siswa siklus II}

\begin{tabular}{|c|c|c|c|}
\hline No & Nama Siswa & $\begin{array}{l}\text { Jumlah Skor } \\
\text { gket kreativitas } \\
\text { Belajar siswa }\end{array}$ & Kriteria Penilaian \\
\hline 1 & Abdul Majid & 52 & Kreativitas baik sekali \\
\hline 2 & Abdul makki & 48 & Kreaativitas baik \\
\hline 3 & Adlina Noviana Hidayat & 47 & Kreativitas baik \\
\hline 4 & Baiq Aisyah & 50 & Kreativitas baik \\
\hline 5 & Bayu Permana & 53 & Kreativitas baik sekali \\
\hline 6 & Deny Kurniawan & 46 & Kreativitas baik \\
\hline 7 & Dzatu Salsabilla Nurdianti & 45 & Kreativitas baik \\
\hline 8 & Elna Sri Hardini & 50 & Kreativitas baik \\
\hline 9 & Frisca Ayudhia Putri & 48 & Kreativitas baik \\
\hline 10 & Grace Davida Dimayanti & 51 & Kreativitas baik sekali \\
\hline 11 & Ifan Cahyoni & 45 & Kreativitas baik \\
\hline 12 & Husnun Niswati & 52 & Kreativitas baik sekali \\
\hline 13 & Julian Salisti & 50 & Kreativitas baik \\
\hline 14 & Lala Sugiatin Hasanah & 45 & Kreativitas baik \\
\hline 15 & Lalu Alfito Dinata & 52 & Kreativitas baik sekali \\
\hline 16 & Lu'lu'atul Husna Izzati & 46 & Kreativitas baik \\
\hline 17 & M. Rizal Alwi & 48 & Kreativitas baik \\
\hline 18 & M. Sadarti & 43 & Kreativitas baik \\
\hline 19 & M. Zamroni Ansyori & 40 & Kreativitas cukup \\
\hline 20 & Mahendra & 45 & Kreativitas baik \\
\hline 21 & Mely Apriana & 52 & Kreativitas baik sekali \\
\hline 22 & Novia Fitriani & 48 & Kreativitas baik \\
\hline 23 & Nurahmadan Noviana & 47 & Kreativitas baik \\
\hline 24 & Rendi Aditia Hariadi & 54 & Kreativitas baik sekali \\
\hline 25 & Rozi Hartono & 53 & Kreativitas baik sekali \\
\hline 26 & Sovia Aprinda & 53 & Kreativitas baik sekali \\
\hline 27 & Sri Cahyani & 45 & Kreativitas baik \\
\hline 28 & Tio Febriansyah & 46 & Kreativitas baik \\
\hline 29 & Urba Anisya & 44 & Kreativitas baik \\
\hline 30 & Wahyuni Fadliatin & 46 & Kreativitas baik \\
\hline 31 & Yuda Pratama & 48 & Kreativitas baik \\
\hline \multirow[t]{3}{*}{32} & Zilmim Habib & 48 & Kreativitas baik \\
\hline & Jumlah total angket & 1540 & - \\
\hline & Nilai rata-rata angket & 48,1 & Kreativitas baik \\
\hline
\end{tabular}


Dari tabel 3, dapat dilihat bahwa nilai rata-rata kreativitas belajar siswa pada siklus II sudah mencapai target yang diharapkan yaitu 48,1, rata-rata siswa memiliki kreativitas belajar yang tergolong kedalam kategori kreativitas baik.

\section{Data Siklus III}

\section{Tahap perencanaan, tahap perencanaan sama dengan siklus I dan II}

\section{Tahap pelaksanaan tindakan}

Pada tahap pelaksanaan tindakan, siklus III di mulai tanggal 28 Mei 2016 dengan materi pokok ekosistem. Data Aktivitas Guru/Keterlaksanaan RPP, terlaksana keseluruhannya, sehingga dapat dikategorikan sangat baik.

\section{Tabel 4}

Hasil Observasi Nilai Angket Kreativitas

Belajar Siswa Siklus III

\begin{tabular}{|r|l|c|l|}
\hline No & Nama Siswa & $\begin{array}{l}\text { Jumlah Skor } \\
\text { angket } \\
\text { kreativitas } \\
\text { Belajar siswa }\end{array}$ & Kriteria Penilaian \\
\hline 1 & Abdul Majid & 54 & Kreativitas baik sekali \\
\hline 2 & Abdul makki & 53 & Kreaativitas baik sekali \\
\hline 3 & Adlina Noviana Hidayat & 53 & Kreativitas baik sekali \\
\hline 4 & Baiq Aisyah & 54 & Kreativitas baik sekali \\
\hline 5 & Bayu Permana & 53 & Kreativitas baik sekali \\
\hline 6 & Deny Kurniawan & 54 & Kreativitas baik sekali \\
\hline 7 & Dzatu Salsabilla Nurdianti & 45 & Kreativitas baik \\
\hline 8 & Elna Sri Hardini & 53 & Kreativitas baik sekali \\
\hline 9 & Frisca Ayudhia Putri & 48 & Kreativitas baik \\
\hline 10 & Grace Davida Dimayanti & 56 & Kreativitas baik sekali \\
\hline 11 & Ifan Cahyoni & 54 & Kreativitas baik sekali \\
\hline 12 & Husnun Niswati & 52 & Kreativitas baik sekali \\
\hline 13 & Julian Salisti & 50 & Kreativitas baik \\
\hline 14 & Lala Sugiatin Hasanah & 45 & Kreativitas baik \\
\hline 15 & Lalu Alfito Dinata & 52 & Kreativitas baik sekali \\
\hline 16 & Lu'lu'atul Husna Izzati & 56 & Kreativitas baik sekali \\
\hline 17 & M. Rizal Alwi & 55 & Kreativitas baik sekali \\
\hline 18 & M. Sadarti & 56 & Kreativitas baik sekali \\
\hline 19 & M. Zamroni Ansyori & 55 & Kreativitas baik sekali \\
\hline & & & \\
\hline
\end{tabular}


Tabel Lanjutan 4

\begin{tabular}{|r|l|c|l|}
\hline No & \multicolumn{1}{|c|}{ Nama Siswa } & $\begin{array}{l}\text { Jumlah Skor } \\
\text { angket } \\
\text { kreativitas } \\
\text { Belajar siswa }\end{array}$ & Kriteria Penilaian \\
\hline 20 & Mahendra & 54 & Kreativitas baik sekali \\
\hline 21 & Mely Apriana & 52 & Kreativitas baik sekali \\
\hline 22 & Novia Fitriani & 56 & Kreativitas baik sekali \\
\hline 23 & Nurahmadan Noviana & 54 & Kreativitas baik sekali \\
\hline 24 & Rendi Aditia Hariadi & 54 & Kreativitas baik sekali \\
\hline 25 & Rozi Hartono & 56 & Kreativitas baik sekali \\
\hline 26 & Sovia Aprinda & 56 & Kreativitas baik sekali \\
\hline 27 & Sri Cahyani & 54 & Kreativitas baik sekali \\
\hline 28 & Tio Febriansyah & 55 & Kreativitas baik sekali \\
\hline 29 & Urba Anisya & 54 & Kreativitas baik sekali \\
\hline 30 & Wahyuni Fadliatin & 52 & Kreativitas baik sekali \\
\hline 31 & Yuda Pratama & 54 & Kreativitas baik sekali \\
\hline 32 & im Habib & 54 & Kreaativitas baik sekali \\
\hline & Jumlah total angket & 1703 & \\
\cline { 2 - 4 } & Nilai rata-rata angket & 53,21 & Kreaativitas baik sekali \\
\hline
\end{tabular}

Dari tabel di atas dapat dilihat bahwa nilai rata-rata nilai kreativitas belajar siswa sudah mencapai target yang diharapkan yaitu 53,21 dari semua siswa yang mengikuti proses pembelajaran. Jadi, dapat disimpulkan bahwa dari siklus I, siklus II sampai siklus III terdapat peningkatan kreativitas belajar siswa, oleh karena itu siklus III dapat disimpulkan dihentikan atau tidak perlu dilanjutkan lagi karena sudah sesuai dengan yang diharapkan.

\section{Pembahasan}

Berdasarkan hasil penelitian yang dieproleh terlihat bahwa dari siklus I sampai siklus III mengalami peningkatan baik pada keterlaksanaan RPP dan kreativitas belajar siswa. berdasarkan hasil observasi aktivitas guru/keterlaksanaan RPP terjadi peningkatan pada keterlaksanaan proses pembelajaran. Pada siklus I persentase keterlaksanaan RPP mencapai 85\%, siklus II dan III mencapai 100\%. Pada keterlaksanaan proses pembelajaran ini terjadi peningkatan dari siklus I ke II, dan siklus II ke siklus III, hal tersebut karena observer selalu memberikan 
saran dan masukan peneliti selaku pengajar sebelum melakukan tindakan.

Pembelajaran dengan metode modeling the way merupakan suatu metode yang dilakuan oleh guru dalam membuat skenario pembelajaran yang akan didemonstrasikan oleh siswa. Untuk mengetahui kreativitas belajar siswa dengan menggunakan metode modeling the way ini peneliti mendapatkan hasil bahwa kreativitas belajar siswa meningkat pada setiap siklus. Peningkatan dapat diketahui dari hasil analisis angket setiap siklus pada tabel dibawah ini.

\section{Tabel 5}

Ringkasan Nilai Kreativitas Belajar Siswa Siklus I, Siklus II dan Siklus III

\begin{tabular}{|c|c|c|l|}
\hline \multirow{2}{*}{ Jenis Data } & \multicolumn{2}{|c|}{ Kreativitas } & \multirow{2}{*}{ Kriteria } \\
\cline { 2 - 3 } & $\begin{array}{c}\text { Jumlah Kreativitas } \\
\text { Seluruh Siswa }\end{array}$ & $\begin{array}{l}\text { Nilai } \\
\text { Rata- }\end{array}$ & \\
\hline Siklus I & 1182 & 36,9 & Kreativitas cukup \\
\hline Siklus II & 1540 & 48,1 & Kreativitas baik \\
\hline Siklus III & 1703 & 52,21 & Kreativitas baik sekali \\
\hline
\end{tabular}

Berdasarkan dari analisis data pada tabel di atas. Pelaksanaan tindakan pada siklus I dikatakan belum berhasil, karena kreativitas belajar siswa masih kurang dalam pembelajaran. Hal ini dilihat dari hasil observasi kreativitas belajar siswa. pada siklus I, hasil observasi kreativitas belajar siswa dengan nialai rata- rata 36,9 dari 32 siswa. Adapun dari analisis data pada siklus II, hasil observasi kreativitas belajar siswa dengan nilai rata-rata 48,1 dari 32 siswa. Hal ini berarti, terjadi peningkatan rata-rata kreativitas belajar siswa dari siklus I ke siklus II sebesar 11,2 Sedangkan dari analisis data pada siklus III, hasil observasi kreativitas belajar siswa dengan nilai rata-rata 53,21 dari 32 siswa. Hal ini berarti, terjadi peningkatan pada kreativitas belajar siswa dilihat dari nilai rata-rata kreativitas belajar siswa siklus II ke siklus III sebesar 5,11.

Dari analisis data pada tabel diatas, pelaksanaan tindakan pada siklus I dikatakan belum berhasil, karena masih terdapat 
siswa yang belum siap menerima pembelajaran dengan menggunakan metode modeling the way ini. Selain itu juga terdapat beberapa faktor yang menyebabkan kreativitas belajar siswa kurang antara lain kurang pemakaian alat peraga atau media pembelajaran seperti lingkungan sekolah tempat kegiatan pembelajaran yang disesuaikan dengan materi pembelajaran dikarenakan lingkungan sekolah yang masih dalam keadaan direnovasi. Belum terlaksana aktivitas guru yang belum menyampaikan tujuan pembelajaran dan menyampaikan materi pokok dalam proses pembelajaran. Siswa masih kurang mampu bekerjasama dengan anggota kelompoknya.

Pada saat kegiatan diskusi terlihat ada siswa yang pasif dan diam, disebabkan karena belum terbiasa diajak untuk belajar berkelompok. Selain itu adanya ketidakcocokan dengan anggota kelompok yang diperoleh, Beberapa siswa masih kurang percaya diri untuk mengutarakan hasil pemikirannya kepada kelompok lainnya. Masih banyak siswa yang belum bisa atau kurang berani menyimpulkan hasil diskusi.

Adapun perbaikan-perbaikan yang dilakukan pada siklus II adalah peneliti sebagai guru menekankan tentang proses pembelajaran dengan metode modeling the way, karena metode ini baru diterapkan di kelas tersebut. Guru menjelaskan sedetail mungkin tentang tujuan dan proses pelaksanaan pembelajaran, selain itu guru menekankan dan memeberikan motivasi siswa agar lebih berani untuk mengutarakan hasil pemikirannya kepada kelompok tanpa harus ragu dalam proses pembelajaran diskusi berlangsung. Dengan perbaikan ini terjadi peningkatan pada kreativitas belajar siswa, akan tetapi masih ada salah seorang siswa yang kurang kreativitasnya sehingga hal ini menyebabkan untuk melanjutkan pada siklus III.

Sedangkan dari analisis pada siklus III kreativitas belajar dengan nilai rata- rata yaitu 53,21 dari 32 siswa. hal ini berarti, terjadi peningkatan pada kreativitas belajar siswa yang dilihat dari nilai individu keseluruhan kreativitas belajar siswa. Hal ini disebabkan karena Perhatian siswa dalam mengikuti pembelajaran semakin meningkat dengan menunjukkan sikap menyimak setiap penjelasan guru, antusiasme dalam pembelajaran, dan menunjukkan rasa senang ketika pembelajaran 
berlangsung. Selain itu juga, keikutsertaan siswa dalam mengikuti pembelajaran semakin meningkat dengan menunjukan sikap menyatakan pendapat, mengajukan pertanyaan.dan kerjasama anatar kelompok terjalin dengan baik

Selain didapatkan dari data hasil penelitian juga dapat diperoleh dari respon beberapa siswa setelah menerapkan metode modeling the way. respon siswa ini dilakukan pada proses pembelajaran berlangsung pada kegiatan refleksi. Mereka mengatakan bahwa mereka sangat senang menggunakan metode modeling the way, karena dalam proses pembelajaran materi yang diajarkan mudah untuk dimengerti, selain itu juga dengan metode modeling the way ini proses pembelajaran sangat menarik.

Oleh karena itu, Peningkatan yang terjadi pada setiap siklus dapat dilihat dari perolehan skor angket yang mengalami peningkatan. Jadi, dapat disimpulkan bahwa penerapan metode modeling the way dapat meningkatkan kreativitas belajar siswa pada materi ekosistem kelas VII MTs. Negeri Jonggat Tahun Pelajaaran 2015/2016.

\section{KESIMPULAN}

Berdasarkan hasil penelitian yang sudah dilakukan, maka dapat ditarik kesimpulan bahwa:

1. Dengan diterapkannya metode modeling the way dapat meningkatkan kreativitas belajar siswa pada materi ekosistem kelas VII MTs. Negeri Jonggat Tahun pelajaran 2015/2016

2. Dapat terlaksananya aktivitas guru/keterlaksanaan RPP yang sudah dikategorikan dalam kriteria sangat baik, dilihat dari siklus I nilai rata-rata keterlaksananaan RPP yatu 85\% , sedangkan siklus II dan siklus III nilai rata-rata keterlaksanaan RPP yaitu $100 \%$. Dengan demikian, terjadi peningkatan aktivitas guru/keterlaksanaan RPP dari siklus I, siklus II dan siklus III.

3. Meningkatnya kreativitas belajar siswa melalui penerapan metode modeling the way pada materi ekosistem kelas VII MTs. Negeri Jonggat Tahun pelajaran 2015/2016 dapat dilihat bahwa pada siklus 1, rata-rata kreativitas belajar siswa sebanyak 36,9. Adapun pada siklus II, rata-rata kreativitas 
belajar siswa sebanyak 48,1. Sedangkan pada siklus III, ratarata kreativitas belajar siswa sebanyak 53,21. Dengan demikian, dari siklus I, siklus II dan siklus III terjadi peningkatan kreativitas belajar siswa pada materi ekosistem.

\section{DAFTAR PUSTAKA}

Achmad Syaiful Ma'arif, Efektivitas Model Pembelajaran Active Learning Tipe Modeling The Way Dalam Meningkatkan Hasil Belajar Peserta Didik Pada Sub Pokok Bahasan Jajar Genjang Dan Belah Ketupat Kelas Vii Di Mts Nu 07 Patebon Kendal Tahun Ajaran 2010/2011. (Skripsi, IAIN Walisongo)

Agus Suprijono. Cooperatif Learning Teori dan Aplikasi PAIKEM. Yogyakarta: Pustaka Pelajar, 2009

Dede Rosyada. Paradigma Pendidikan Demokratis. Jakarta: Kencana, 2007. Drs. Slameto, Belajar Mengajar \& FaktorFaktor Yang Mempengaruhinya. Jakarta: Rineka Cipta, 2010

Ernia faryani, Peran Guru Pada Pembelajaran Demokratis Dalam MeningkatkanKreativitas Belajar Siswa Pada Mata Pelajaran Ekonomi Kelas XI SMAN 1 Keruak Tahun Pelajaran 2013/2014.(skripsi IAIN Mataram)

Hamruni. Strategi Pembelajaran. Yogyakarta: Insan Madani, 2012.

Hamzah B. Belajar dengan Pendekatan PAILKEM. Jakarta: Bumi Aksara, 2014.

John W. Santrock, Psikologi Pendidikan, Jakarta: Salemba 
LESTARI WAHYU PUTRI, DKK

Humanika, 2011

Mahmud. Metode Penelitian Pendidikan, Bandung: Pustaka Setia, 2011

Masnur, Melaksanakan Penelitian Tindakan Kelas (PTK) Itu Mudah, Jakarta: PT Bumi Aksara, 2011

Mohammad Asrori. Psikologi Pembelajaran. CV Wacana prima, 2009.

Nana Syaodih sukmadinata. Pengembangan Kurikulum Teori dan Praktik Bandung : PT Remaja Rosdakarya, 2009.

Nurmala Agustin, Penggunaan Media Pembelajaran Teka-Teki Silang Dalam Meningkatkan Kreativitas Belajar Siswa Kelas VI pada Mata Pelajaran IPS Tahun Pelajaran 2013/2014, (skripsi IAIN Mataram)

Nurwulan Titik. Implementasi Metode Modelling the Way dalam Meningkatkan Kualitas Pembelajaran Matematika Siswa Kelas IV MI Ma'arif Surodikraman Ponorogo Tahun Pelajaran 2011/2012. (Skripsi, Program Studi Pendidikan Matematika Universitas Muhammadiyah Ponorogo)

Oemar Hamalik. Proses Belajar Mengajar. Jakarta: Bumi Aksara , 2009.

Purwanto Ngalim, Prinsip-Prinsip dan Teknik Evaluasi Pengajaran, Bandung: PT Remaja Rosdakarya, 2010

Seto Wardono, Lingkungan Hidup. Pilar Bambu Kuning, 2001

Suharsimi Arikunto, Prosedur Penelitain. Jakarta: Rineka Cipta, 2002

Tim Penyusun, Pedoman Penulisan Skripsi. Mataram: IAIN, 2010

270 BIOTA: Jurnal Tadris IPA Biologi FITK IAIN Mataram 
Wina Sanjaya, Pembelajaran dalam Implementasi Kurikulum Berbasis Kompetensi. Jakarta: kencana, 2006

Yatim Riyanto, Metodologi Penelitian Pendidikan. Surabaya: SIC, 2006

Zoer'aini Djamal Irawan, M.Si. Prinsip-Prinsip Ekologi: Ekosistem, Lingkungan dan Pelestariannya. Jakarta: bumi aksara, 2003 